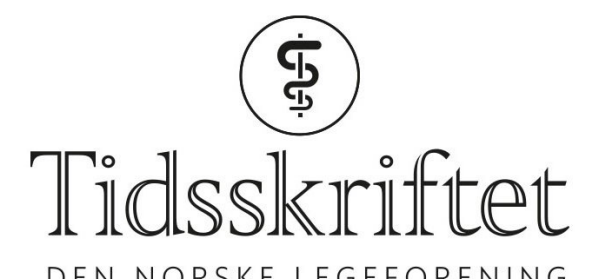

DEN NORSKE LEGEFORENING

\title{
Tidsmerking av genuttrykk i enkeltceller
}

FRA ANDRE TIDSSKRIFTER

RUTH HALSNE

Tidsskriftet

En ny metode gjør det mulig å se hvordan genuttrykket endrer seg over tid i en enkelt celle.

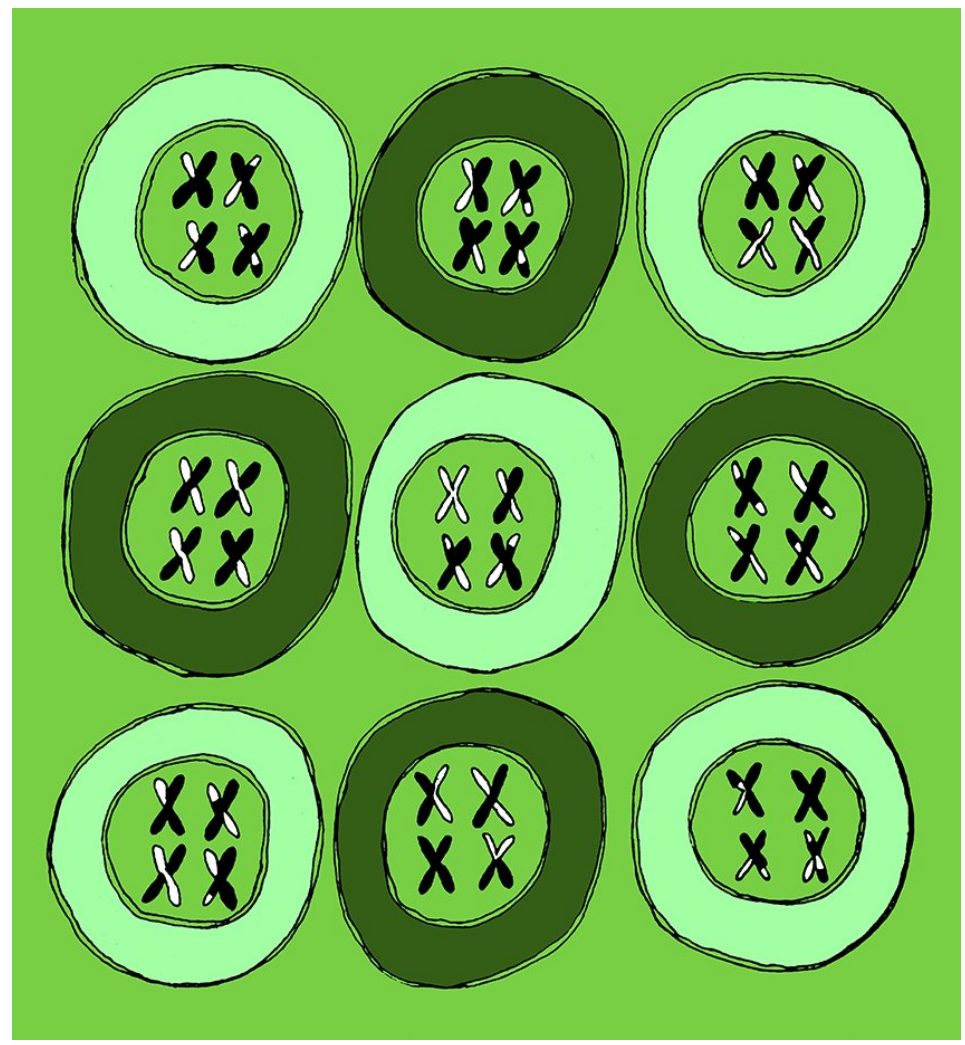

Illustrasjon: Science Photo Library / NTB

Sensitiviteten ved sekvensering er høy nok til å sekvensere RNA i en enkelt celle og dermed oppnå et øyeblikksbilde av genuttrykket i cellen. En nyutviklet metode gjør det mulig å se på dynamikken for når de ulike genene er aktive i en celle (1).

Et tidsstempel (timestamp på engelsk) som merket RNA, ble designet ved å bruke spesifikke RNA-bindingsseter som rekrutterer proteinet MS2, som igjen binder til adenosindeaminase-enzymet ADAR2. Med ADAR2-enzym bundet til RNA ble nysyntetisert RNA merket metabolsk ved at adenosin ble gjort om til inosin. Akkumulerte metabolske endringer samsvarte med $ø$ kende mengde tidsenheter. Ved sammenligning av gener styrt 
av samme promoter kunne man skille eldre og nyere RNA-sekvenser. Denne tidsmerkingen gjorde at det som før var et øyeblikksbilde, nå gav mer dynamisk informasjon.

- Denne er metoden er nok et eksempel på hvordan måling av genuttrykket blir stadig mer presis og gir stadig mer informasjon, sier Christiaan Henkel, som er forsker ved Norges miljø- og biovitenskapelige universitet på Ås.

- Vi kan måle nivået av et genuttrykk på enkeltcellenivå, men med informasjon over tid kan man oppnå helt ny kunnskap om cellens aktivitet over tid og cellens reaksjoner på ulike hendelser. Metoden som er brukt i denne studien, er foreløpig begrenset til enkelte gener i en cellelinje, men prinsippet med å registrere spesifikke, kjemiske RNA-endringer over tid kan utvikles videre. Det finnes over hundre kjente nukleotidmodifikasjoner og flere sekvenseringsteknologier som sammen gir store muligheter, sier Henkel, som håper at vi med slike metoder en dag kan danne oss et mer komplett bilde av hvordan alle genene uttrykkes i en celle.

LITTERATUR:

1. Rodriques SG, Chen LM, Liu S et al. RNA timestamps identify the age of single molecules in RNA sequencing. Nat Biotechnol 2020;38. doi:10.1038/s41587-020-0704-z. [PubMed][CrossRef]

Publisert: 1. februar 2021. Tidsskr Nor Legeforen. DOI: 10.4045/tidsskr.20.0915

(C) Tidsskrift for Den norske legeforening 2020. Lastet ned fra tidsskriftet.no 